\title{
Metastatic conventional prostatic adenocarcinoma with diffuse chromogranin $A$ and androgen receptor positivity
}

\author{
M P Roudier, L D True, R L Vessella, C S Higano
}

J Clin Pathol 2004;57:321-323. doi: 10/1136/jcp.2003.010207

Conventional prostate adenocarcinomas consist mainly of tumour cells of luminal immunophenotype with scattered neuroendocrine (NE) cells. NE cells are defined by chromogranin A (CGA) immunoreactivity. Unlike luminal cells, NE cells lack androgen receptor (AR) and prostate specific antigen (PSA) immunoreactivity. This report describes the first case of conventional prostate adenocarcinoma expressing CGA, PSA, and AR as determined by immunohistochemistry. A 64 year old man was diagnosed with conventional prostate adenocarcinoma in 1993; he underwent cystoprostatectomy in 1994; he developed an iliac bone metastasis in 1997 and mediastinal lymph node metastases in 1999. All specimens obtained during the progression of the disease consisted primarily of luminal cells with only scattered NE cells. In contrast, in samples of non-osseous and osseous metastases obtained at necropsy in 2001, greater than $80 \%$ of tumour cells were shown to express PSA, AR, and CGA. This suggests that during tumour progression, conventional prostate adenocarcinomas may evolve into an NE cell phenotype.

E xcept in rare prostate cancers with extensive or complete neuroendocrine (NE) differentiation, such as small cell carcinoma and carcinoid-like tumours, NE expression in conventional prostate carcinoma is, at most, rare and focal in nature. ${ }^{1}$ NE differentiation is defined by the presence of tumour cells that have a chromogranin A (CGA) immunoreactivity. ${ }^{1}$ Typically, prostate cancer NE cells do not express immunoreactive androgen receptor (AR) or prostate specific antigen (PSA). ${ }^{2}$ We report a patient in whom more than $80 \%$ of metastatic prostate cells expressed all three markers.

\section{CASE REPORT}

A 64 year old man presented with a serum PSA concentration of $6.5 \mathrm{ng} / \mathrm{ml}$ in 1993. He underwent prostate biopsy and was diagnosed with a $4 \mathrm{~mm}$ focus of prostatic adenocarcinoma, Gleason combined score $3+2=5$. In 1994, after careful monitoring, repeat biopsies showed a prostatic adenocarcinoma, Gleason combined score $3+3=6$. At radical prostatectomy, the tumour volume was $10 \mathrm{ml}$, with a Gleason score of $3+4=7$. The seminal vesicles and obturator lymph nodes were also involved. Postoperatively, the patient was treated with combined hormonal ablation. In April 1997, the serum PSA had increased from $<0.1$ to $0.5 \mathrm{ng} / \mathrm{ml}$, and a bone scan showed solitary uptake in the right ileum. A subsequent biopsy confirmed prostate cancer metastasis and the lesion was treated with radiotherapy. In 1999, the patient developed bilateral pulmonary metastases with extensive mediastinal adenopathy. At that time, the serum PSA was only $9 \mathrm{ng} / \mathrm{ml}$. Despite treatment, and a short term response with different chemotherapeutic regimens, the patient died with widespread osteoblastic bone metastases in
2001, at which time his serum PSA was $701 \mathrm{ng} / \mathrm{ml}$. NE activity was not observed clinically during the progression of the disease.

The patient consented to participate in our prostate cancer donor rapid necropsy programme. ${ }^{3}$ At necropsy, all obvious non-osseous metastatic sites and bone biopsies from 20 preselected sites were sampled. There was diffuse metastatic bone involvement, in addition to small metastases in the liver and lymph nodes. There was no evidence of other primary carcinoma. Bone samples were decalcified using a 10\% formic acid and oxalate ammonium method and then processed for conventional histology as for the non-osseous samples. Samples were cut for haematoxylin and eosin sections. As part of the programme, $5 \mu \mathrm{m}$ sections of all metastases (and of the initial biopsies) were dried overnight on precharged slides (Precleaned Superfrost Plus; VWR Scientific, West Chester, Pennsylvania, USA). They were then immunostained with a polyclonal antibody to PSA $(3 \mu \mathrm{g} / \mathrm{ml}$ in phosphate buffered saline (PBS); A0562; Dako, Glostrup, Denmark), a monoclonal antibody to CGA (LK2H10; at a l/ 32000 dilution in PBS; Boehringer Mannheim, Mannheim, Germany), a monoclonal antibody to the AR (F39.4.1; at a 1/ 500 dilution in PBS; Biogenex, San Ramon, California, USA), and a polyclonal antibody to Ki67 (Ki67; at a 1/75 dilution in PBS; Dako). Antigen retrieval methods were performed before CGA and Ki67 staining using citrate buffer $(0.01 \mathrm{M}$, $\mathrm{pH} 6$, in a pressure cooker for 10 minutes) and before AR staining using Tris buffer $(0.5 \mathrm{M}, \mathrm{pH} 10,15$ minutes $)$. Immunostaining was done using the automated Ventana system (Nexes; Ventana Medical Systems Inc, Tucson, Arizona, USA), which uses an indirect avidin-biotin-peroxidase technique, with diaminobenzidine as the chromogen for the antigen localisation. Rabbit IgG and mouse IgG at the same concentration as the corresponding primary antibodies were used as negative controls. Two pathologists (MPR and LDT) independently scored each slide for the percentage of immunostained tumour cells at each sample site.

All specimens (diagnosis biopsy, radical prostatectomy, and iliac bone biopsy) were retrieved a posteriori and consisted primarily of PSA and AR immunoreactive luminal cells, with scattered CGA immunoreactive NE cells representing less than $1 \%$ of all tumour cells. The bone metastases acquired at the rapid necropsy consisted of tumour cells forming glands without tumour grade progression as compared with the initial Gleason score of 7 . The bone metastases consisted of a median of $100 \%, 80 \%$, and $40 \%$ tumour cells immunoreactive for PSA, CGA, and AR, respectively. Approximately $10 \%$ of the tumour cells expressed Ki67. In the non-osseous metastases, $90 \%$ of the

Abbreviations: $A R$, androgen receptor; $C G A$, chromogranin $A ; N E$, neuroendocrine; PBS, phosphate buffered saline; PSA, prostate specific antigen 

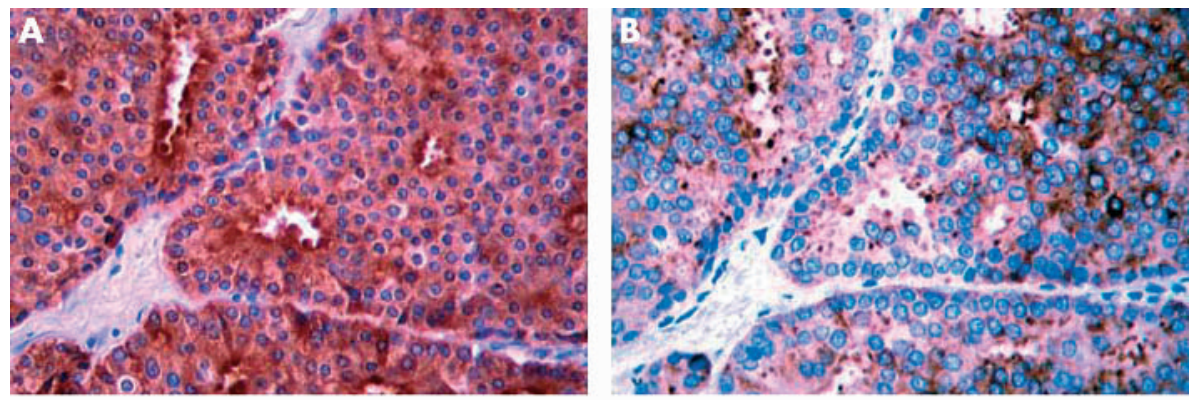

Figure 1 Immunostaining of serial sections of a representative lymph node metastasis taken at necropsy showing coexpression of $(A)$ prostate specific antigen, (B) chromogranin $A,(C)$ androgen receptor, and (D) Ki67. Original magnification, $\times 400$.
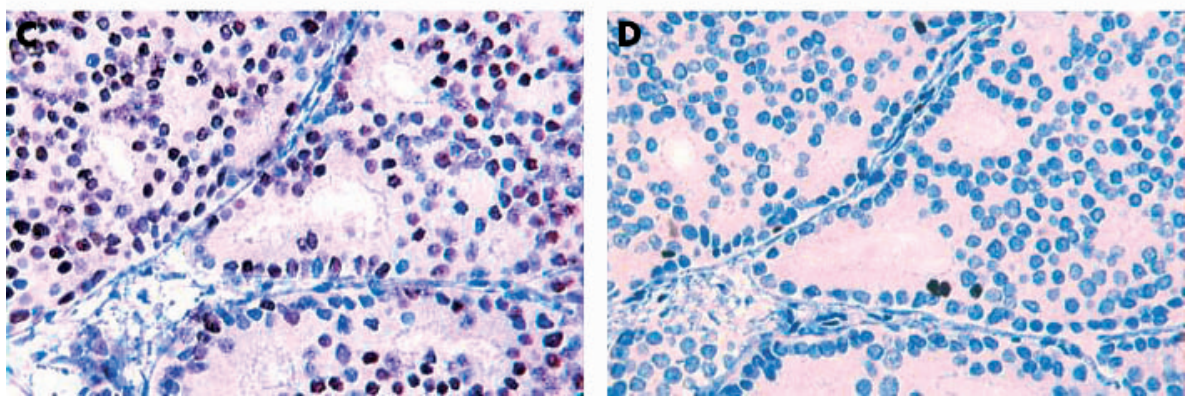

tumour cells expressed the AR, with $80 \%$ of the cells expressing CGA and PSA, and approximately $2 \%$ of tumour cells expressed Ki67. Figure 1 shows representative samples of this expression.

\section{DISCUSSION}

NE differentiation in prostate cancer is associated with poor prognosis, tumour progression, and an androgen independent state. ${ }^{14} \mathrm{NE}$ cells are thought not to express the AR and are therefore unaffected by androgen deprivation. ${ }^{2}$ During the androgen independent state of the disease, the tumour NE cell fraction is believed to increase compared with that during the androgen dependent state, as reflected in CGA tissue immunostaining and rising serum concentrations of $\mathrm{CGA}^{5-7}$ This has led to the hypothesis that prostatic NE tumour cells, lacking AR, represent an androgen insensitive cell population, which may expand to replace the androgen sensitive tumour cell population during hormone ablation treatment.
"Our case demonstrates for the first time that an intermediate or hybrid cell type, having both nonneuroendocrine and neuroendocrine cell features, can occur in a conventional prostate carcinoma"

Our patient presented with a history that is classic for prostate carcinoma, with sequential metastases to regional lymph nodes then bone. The tumour was histologically typical of a primary adenocarcinoma during the progression of the disease, expressing PSA and AR and lacking CGA immunoreactivity over the six years of disease progression (fig 2). During the last year of progression, tumour cells acquired an NE phenotype (that is, CGA staining), albeit maintaining a conventional adenocarcinoma morphology with glandular formation and nuclei with a prominent nucleolus in the centre (fig 1). In pheochromocytoma cells, CGA has been shown to be an early on/off switch controlling neurosecretory granule biogenesis, leading to the hypothesis that these cells are in a transition state to a more developed

\begin{tabular}{|c|c|c|c|}
\hline 1994 & 1997 & 1999 & 2001 \\
\hline $\begin{array}{l}\text { Prostate } \\
\text { adenocarcinoma }\end{array}$ & $\begin{array}{l}\text { Iliac bone } \\
\text { metastasis }\end{array}$ & $\begin{array}{l}\text { Mediastinal } \\
\text { lymph nodes } \\
\text { metastases }\end{array}$ & $\begin{array}{l}\text { Multiple metastases } \\
\text { at necropsy }\end{array}$ \\
\hline $\begin{array}{l}\text { No CGA cells in biopsied } \\
\text { adenocarcinoma, scattered } \\
\text { NE cells in radical } \\
\text { prostatectomy tumour, PSA } \\
\text { and AR positive tumour } \\
\text { cells }\end{array}$ & $\begin{array}{l}\text { No CGA cells } \\
\text { in iliac bone } \\
\text { metastasis, } \\
\text { PSA and AR } \\
\text { positive tumour } \\
\text { cells }\end{array}$ & $\begin{array}{l}\text { No CGA cells in } \\
\text { mediastinal lymph } \\
\text { nodes, PSA and AR } \\
\text { positive tumour cells }\end{array}$ & $\begin{array}{l}\text { More than } 80 \% \text { of CGA } \\
\text { cells in non-osseous and } \\
\text { osseous metastases, PSA } \\
\text { and AR positive tumour } \\
\text { cells }\end{array}$ \\
\hline
\end{tabular}

Figure 2 Schematic representation of chromogranin A positivity at different time points during the disease progression. $A R$, androgen receptor; CGA, chromogranin $\mathrm{A} ; \mathrm{NE}$, neuroendocrine; PSA, prostate specific antigen. 


\section{Take home messages}

- We report a conventional prostate adenocarcinoma that initially expressed prostate specific antigen (PSA) and the androgen receptor (AR)-typical of luminal cells - but on progression also expressed chromogranin A (CGA)-typical of neuroendocrine (NE) cells

- Our case demonstrates for the first time that an intermediate or hybrid cell type, having both non-NE and NE features, can occur in a conventional prostate carcinoma

- This suggests that during tumour progression, conventional prostate adenocarcinomas may evolve into an NE cell phenotype

- It still remains to be demonstrated in a cohort of similar cases that poor prognosis is secondary to the switch to an NE phenotype

NE status. ${ }^{8}$ Our case demonstrates for the first time that an intermediate or hybrid cell type, having both non-NE and NE features, can occur in a conventional prostate carcinoma. It still remains to be demonstrated in a cohort of similar cases that poor prognosis is secondary to the switch to an NE phenotype.

\section{ACKNOWLEDGEMENTS}

Funding for this work was provided by an OBRIEN award from the NIDDK (number 2 P50 DK47656-10), an NIH Prostate Cancer SPORE grant (NCI 1P50CA97186-01), the Richard M Lucas Foundation, and the CaP CURE Foundation.

\section{Authors' affiliations}

M P Roudier, R L Vessella, Department of Urology, University of

Washington, 1959 NE Pacific Street, Box 356510, Seattle, WA 98195,

USA

L D True, Department of Pathology, University of Washington

C S Higano, Department of Medicine, University of Washington

Correspondence to: Dr M P Roudier, Department of Urology, University of Washington, 1959 NE Pacific Street, Box 356510, Seattle, WA

98195, USA; mroudier@u.washington.edu

Accepted for publication 4 September 2003

\section{REFERENCES}

1 di SantAgnese PA. Neuroendocrine differentiation in prostatic carcinoma: an update on recent developments. Ann Oncol 2001;12(suppl 2):S135-40.

2 Bonkhoff H, Stein U, Remberger K. Androgen receptor status in endocrine-paracrine cell types of the normal, hyperplastic, and neoplastic human prostate. Virchows Arch A Pathol Anat Histopathol 1993;423:291-4.

3 Roudier MP, True LD, Higano CS, et al. Phenotypic heretogeneity of androgen-independent prostate cancer bone metastases. Hum Pathol 2003;34:646-53.

4 Krijnen JL, Bogdanowicz JF, Seldenrijk CA, et al. The prognostic value of neuroendocrine differentiation in adenocarcinoma of the prostate in relation to progression of disease after endocrine therapy. J Urol 1997; 158:171-4.

5 Jiborn T, Bjartell A, Abrahamsson PA. Neuroendocrine differentiation in prostatic carcinoma during hormonal treatment. Urology 1998;51:585-9.

6 Jongsma J, Oomen MH, Noordzii MA, et al. Androgen deprivation of the PC310 [correction of prohormone convertase-310] human prostate cancer model system induces neuroendocrine differentiation. Cancer Res 2000;60:741-8.

7 Isshiki S, Akakura K, Komiya A, et al. Chromogranin A concentration as a serum marker to predict prognosis after endocrine therapy for prostate cancer. J Urol 2002; 167:512-15.

8 Kim T, Tao-Cheng JH, Eiden LE, et al. Chromogranin A, an "on/off" switch controlling dense-core secretory granule biogenesis. Cell 2001;106:499-509. 